\title{
Application of Electron Scanning Microscope in the Analysis of the Structure of Casting Non- Conformities Aimed at Optimization of Technological Process Parameters
}

Czajkowska Agnieszka, Kossakowski Paweł, Wciślik Wiktor, Stasiak-Betlejewska Renata

Faculty of Civil and Environmental Engineering, Kielce University of Technology al. Tysiąclecia Państwa Polskiego 7, 25-314 Kielce e-mail: a_czajkowska@o2.pl

The structural content of castings and non-conformities that might occur in pressure die casting is mainly connected with technological parameters. Analysis of the casting structure helps identify a group of causes of nonconformities which are connected with improper choice of technological parameters. The non-conformities identified in the pressure die castings discussed in the paper were analysed by means of metallographic examinations. A electron scanning microscope was used in the study for the analysis of the structure of casts. This analysis allowed for identification of the causes of e.g. shrinkage depressions or misruns. The analysis of the structure of a casting in the location of the depression revealed insufficient cooling time used for this casting.

Keywords: pressure die casting, non-conformities, AlSi alloys

\section{References}

[1] MICHNA, Š., LUKÁČ, I., NÁPRSTKOVÁ, N. (2009). Optimalizace mechanických vlastností u slitiny AlSi12CuMgNi. Strojírenská technologie ročník XIV/2. pp. 9-14ISSN 1211-4162.

[2] VAJSOVÁ, V., NÁPRSTKOVÁ, N. (2009). Structural Inhogomenity by Al-Cu Alloys Casting into Metal and Bentonic Form. In ,10th International Scientific Conference Automation in Production Planning and Manufacturing, 4-6.5. Turčianské Teplice, SR. ISBN 978-80-554-0008-2.

[3] KONOPKA, Z., CISOWSKA, M. (2002). Ocena płynięcia ciekłego stopu AlMg10 w spiralnej próbie lejności, In: Archiwum Odlewnictwa, Vol. 2, No 4.

[4] http://www.przeglad-techniczny.pl/arch/2006/12/daleka_droga.htm, 12.06.2009.

[5] PRZYBYŁOWICZ, K. (1994). Metaloznawstwo. Wydawnictwo WNT, Warsaw 1994

[6] DOBRZAŃSKi, L. (2008). Metaloznawstwo opisowe stopów metali nieżelaznych, Wydawnictwo Politechniki Śląskiej, Gliwice.

[7] BALAWENDER, R., KONOPKA, Z. (2006). Ocena stopów magnezu dla odlewnictwa ciśnieniowego. In: VII Międzynarodowej Konferencji Naukowej. Nowe technologie i osiagnięcia w metalurgii i inżynierii materiałowej, Częstochowa.

[8] Barcik, J., Kupka M., Wala A. 2000. Technologia metali, Vol. 2. System i Techniki Wytwarzania, Wydawnictwo Uniwersytetu Śląskiego, Katowice.

[9] CZAJKOWSKA A., BORKOWSKI, S. 2009. Chapter 8. Metallographic testing of AlSi alloys as a part of visual inspection. In: Toyotarity. Visual Control (Editing and Scientific Elaboration S. Borkowski, E. B. Tsoy), Publishing Makovetsky, Dnipropetrovsk.

[10] PIETROWSKI, S. (2008). Wysokojakościowe odlewy ciśnieniowe z siluminów. In: Innowacje w odlewnictwie ciśnieniowym. part I, Wydawnictwo Instytutu Odlewnictwa, Kraków.

[11] BORKOWSKI, S., STASIAK-BETLEJEWSKA, R._, NÁPRSTKOVÁ, N. 2011.' The Kaizen philosophy in the aluminium products improvement, Manufacturing Technology, Volume 11, Pages 2-5

[12] SUJANOVA, J., GABRIS, P., LICKO, M., PAVLENDA, P., STASIAK-BETLEJEWSKA, R. 2012_ Aspects of knowledge management in Slovak industrial enterprises, Proceedings of the European Conference on Knowledge Management, ECKM, Volume 2, 2012, Pages 1135-1144, 13th European Conference on Knowledge Management, ECKM 2012;Cartagena;6 September 2012through7 September 2012.

[13] TILlOVÁ, E., FARKAŠOVÁ, M., CHALUPOVÁ, M, 2013 The role of antimony in modifying of Al-Si-Cu cast alloy, Manufacturing Technology, Voume 13, , ISSN 1213-2489

[14] NOVÁ I, MACHUTA, J. 2013. Squeeze casting results of aluminium alloys, Manufacturing Technology|Voume 13, ISSN $1213-2489$

[15] MICHALCOVA, A, VOJTĚCH, D. 2012. Structure of rapidly solidified aluminium alloys, Manufacturing Technology | Voume 12, ISSN 1213-2489 